\title{
Between Global Inequalities and World Ethics. Personal Reflections on Internationalisation of Higher Education over the Past Seventy Years
}

\author{
Pavel Zgaga
}

When the IAU was founded on 9 December 1950, I had just been conceived. We "met" each other only in the 1990s, but I think it is fair to say that the IAU's seventy years are, in a sense, also my almost seventy years. We both share one aspect of this historical period: the IAU at the macro-level and I at the micro-level. There is no doubt that we are of the same generation.

Until years and experiences are gathered, people look with hope and great expectations at the many paths that will open up before them. But as the years go by, opportunities for reflection and rethinking gradually open up. This is why, on the occasion of the 70th anniversary of such a prestigious association as the IAU, I cannot help but reflect on the time that lies behind us and focus, at least on some points, on the hopes and perspectives: not those of half a century ago, but those we have to face today.

So how has the stream of internationalisation of higher education progressed over this long period, how have we been rowing in it, have we ever got lost in the side arms of the river, how far have we finally come, and what challenges do we now face in choosing a further path? These many questions, however, must be answered in short.

I look at these questions first from the perspective of the micro-level. The generation born around 1950 was referred to as the "baby boomers". It is the generation that personally did not experience the cruellest period in history; and since experience is always the limiting factor, this generation was free to face the inherited situation without prejudice. It is the generation that enrolled in universities in the second half of the 1960s-and soon wrote the graffiti May 1968 on the walls of university history.

From a macro-level perspective, this period corresponded to the "growing up" of the IAU and similar associations and organisations. The revival of endangered cul-

P. Zgaga ( $ه)$

University of Ljubljana, Ljubljana, Slovenia

e-mail: Pavel.Zgaga@guest.arnes.si

(C) The Author(s) 2021

H. van't Land et al. (eds.), The Promise of Higher Education,

https://doi.org/10.1007/978-3-030-67245-4_8 
tural values and the severe destruction of civilisation in the Second World War also placed new demands on the mission of universities on a global scale. The advancement of knowledge in research and its dissemination through teaching and learning, regardless of linguistic, cultural, geographical and other differences, was a fundamental principle of the Enlightenment of both ancient and modern civilisations. However, in the harsh first half of the twentieth century, national higher education systems moved away from each other rather than converging and cooperating more closely. The end of World War II brought with it the hope that the pursuit of knowledge, its dissemination and application would also confirm its cosmopolitan and humanistic potential.

This vision met with great obstacles. In addition to the traditional ones, these were now mainly the complex processes of the Cold War on the one hand and decolonisation on the other. Under the conditions of changing global relations and new political and military escalations in the world, it was necessary to counter the dominant centres of world powers with a cosmopolitan and humanist vision. In this context, a particularly challenging space has opened up for higher education. It has been a challenge for universities to affirm their role in society based on proven academic values. This challenge led, among other things, to the founding of the IAU. In other ways, the same challenge was also symbolically reflected in the values that May 1968 brought to the clouds of tear gas in many countries around the world. A new - and very numerous - generation entered the universities full of enthusiasm. A new chapter in the development of higher education began.

I enrolled at the University of Ljubljana in 1970. After graduating from high school, I attended a two-week summer school in a Europahuis near Maastricht, where I was first acquainted with the idea of a united Europe and had an exciting time in the international society of peers and lecturers. Afterwards, I spent another two weeks with friends in a student residence in Amsterdam. A whole new window to the world opened up to me that summer. In autumn, with the beginning of lectures at my home university, the student movement in our country reached its peak. On the agenda were both the "social dimension" of higher education, as we call it today, and a broad agenda of tough questions regarding domestic and foreign politics. At the forefront was the American aggression in Vietnam and the Soviet aggression against Czechoslovakia-in connection with various issues of global inequality and world ethics.

We, the students - certainly not only students of social sciences and the humanities - came to understand that real life is the best laboratory and classroom, where it is really possible to test theoretical knowledge and at the same time train for active citizenship. For the first time in my life, I encountered concepts such as academic freedom and university autonomy, and also that the academic space cannot recognise external boundaries that might hinder or prevent it. Il est interdit d'interdire, was written on a wall by Parisian students with whom we had direct contact. I still remember a sharp street protest, organised in their support, during the official visit of the French Prime Minister Chaban-Delmas to our city. We also kept contact with students from other countries and of course from Zagreb and Belgrade, the cities of the then common state. In the summer, we went to the Croatian island 
of Korčula, where we listened to lectures from famous Yugoslav (Praxis group) and international professors (among others, Agnes Heller, Herbert Marcuse, Erich Fromm, Jürgen Habermas, Henri Lefebvre, Lucien Goldmann). Last but not least, there were many foreign students in our dormitory, especially from the then so-called non-aligned countries, who gave us insights not only into the restless processes of decolonisation, but also into other cultures and thus into intercultural understanding. When I graduated, the idea — and the practical necessity — of global inter-university cooperation was no longer unknown to me at all.

This idea accompanied me through all the years of my professional career. In the 1980s, I experienced it primarily as the manifestation of a wide gap between a personal desire for international cooperation and many, mainly financial, obstacles that prevented its realisation. I remember that at the end of the $1980 \mathrm{~s}$, I drove with three other colleagues in a car to a conference in Oxford; in addition to personal luggage, we had an even larger quantity of cheap domestic petrol with us. We were caught red-handed by the police while filling up somewhere in the middle of Germany; the policemen were very kind, but we had to hand over the jerry can and refuel at the official petrol pump. But the conference was brilliant; we refuelled our intellectual batteries and created a new network of international contacts. Shortly afterwards, we met TEMPUS, i.e., the European Union programme to intensify cooperation in higher education with Central European countries undergoing profound social and political transition during that time. TEMPUS, a kind of parallel to ERASMUS, enabled us to fully understand what international academic mobility means and what potential it has.

But we also recognised the importance of organisational frameworks that enable and promote international cooperation. We were proud that in 1988 our university participated in the signing ceremony of the Magna Charta Universitatum in Bologna. For us, however, the transition to the 1990s had to do with the establishment of an independent state and a rather arduous path towards its international recognition. Among other things, this transition gave us the opportunity to join international organisations and associations: first and foremost, the United Nations, UNESCO and the Council of Europe, the pre-accession negotiations with the European Union, etc., and in this context higher education also had its own agenda. Academic networks had multiplied; the institutional and, not least, the much-needed legislative and policy framework for higher education had been strengthened. I had the privilege of participating, on behalf of my new-born country, the Republic of Slovenia, in the adoption of two documents which have had a profound impact on European and international cooperation in higher education: the 1997 Lisbon Recognition Convention and the 1999 Bologna Declaration.

Since then, a lot of water has flowed down the river, and many ground-breaking events have taken place in international higher education. During this period, the importance of international cooperation - either when I look at it personally, or when it concerns my university or my country, or Europe and the whole world-has grown enormously, while at the same time its characteristics have changed radically. In the 1950s, it was crucial to establish strong and lasting links between universities around the world. This was a fragmented and conflict-ridden post-war world in 
which it was not only necessary to advance and disseminate knowledge, but also to strengthen mutual understanding and global cooperation in the world. The turn from the 1960s to the 1970s heralded the era of mass higher education, which included a fundamental transformation of higher education, in particular the shift from access to higher education as a privilege to access to higher education as a right ("equally accessible to all on the basis of merit", if we use the language of the Universal Declaration of Human Rights). The 1990s shifted internationalisation into a higher gear; higher education systems worldwide expanded at an incredible rate, and the number of mobile students - and staff - increased exponentially. We believed that we were entering a knowledge society that would lead us, in perspective, to even closer global cooperation. But they were also years marked by a progressive, yet deeply contradictory, globalisation, with neoliberal pressures driving the commodification of higher education.

Thirty years have passed, and in analogy to earlier epochs in history, the idea has arisen that we may be experiencing a new era of transformation, in which a hitherto familiar Zeitgeist is on track to crash into something completely different and unknown. The process of globalisation, which seemed to be unstoppable at the time, has been confronted in recent years with (confronted with? really? maybe it has just turned into) deglobalisation, renationalisation. The political, economic and social processes of gradual international distancing (more on this concept later) which is accompanied by the promotion of "national pride" today, have also had a strong impact on the field of science and higher education, directly or indirectly.

Now, at the end of May 2020, there is no longer any doubt: this year will certainly be marked as another decisive turning point, both in general and with regard to higher education and its internationalisation in particular. It is still too early to make definitive statements, but it is the right time to ask questions and formulate hypotheses. It seems that all it took was an external, completely unexpected and initially quite amazing lever, called COVID-19, to see the problems that have been slowly accumulating for some time in a new light.

In many countries, schools and universities were closed practically overnight. Mobility was stopped. The reassuring statements that we are now living in the digital age and that we can replace the "old" physical world with a "new" virtual world have proven to be a great illusion. The problems we know from the physical world have only multiplied in the virtual world. People remain physical beings and still need the physical world, but they also need a safe and free world, both physical and virtual. However, security and freedom cannot really be guaranteed unless at least the basic principles of equality are enforced in the world. Expanding access to education was seen as a prospect for better times. But the more education has become a mass education, the more clearly educational inequalities have become detectable. We all know that, on a global scale, an immeasurably small percentage of people control an immeasurably large part of wealth. (I recently read in the media that this gap has even widened during the pandemic). This process also has consequences for education. The quantity and quality of knowledge is growing exponentially, yet while for some people the opportunities for (private) top-level education are growing, for many people the (public) educational opportunities are in fact deteriorating. The 
current pandemic, as we read in the media, has launched millions of children and young people - especially in the developing countries—back into a world without schools. It is often believed that learning failures, absenteeism, dropouts, etc. are phenomena that originate on the individual level. No, this is a systemic problem and also a problem of civilisation. Similar to a pandemic.

One would expect higher education at a local and global level to be more sensitive to these and similar issues. But we are dealing with a strange paradox: The more ethical principles are emphasised in academic life, the more fraud is reported. There is an urgent need to broaden the scope of the objectives of higher education beyond purely instrumental goals and to rethink its humanistic potential. How can today's higher education contribute to its community and to society as a whole? The current pandemic poses a major challenge in this direction: the search for resources to help people in need-be it in medicine, communications, economics, social work or education-requires the most advanced knowledge. But this knowledge must not be deemed a means of profit; its value resides in the notion that it is needed to care for people. What are the means and what are the ends? This is a big question, also today.

The time of the pandemic spares neither language nor meaning. In recent months there has been a constant and very loud call for social distancing. This term sends out a false, thoughtless message. What must be respected and practised in a health crisis is physical distancing, because we must stop the physical transmission of the virus from one person to another. We must, therefore, make a loud appeal for physical distancing, while at the same time strengthen social proximity, social cohesion and cooperation. We must not risk weakening or even losing them in this crisis. At a local, national and global level. We can only resolve this crisis and defeat the virus as closely linked social beings. And we must deal with other "viruses" in the same way.

In the late 1980s, there was a heated debate in the wake of the British Prime Minister Margaret Thatcher's statement that "there is no such thing as a society". But global shocks, like a pandemic, prove that there definitely is a society. If we were just isolated, distanced individuals, there would be no danger. In a time of a pandemic, we need physical distance to protect ourselves as a society, as a civilisation; but we can only be truly protected if the close social bond is strengthened, not weakened. All this also applies to international cooperation in higher education. In the coming period, universities and their international associations will have to rise to the challenge as they have an important role to play.

Pavel Zgaga is Professor of Philosophy of Education at the Faculty of Education, University of Ljubljana, Slovenia. He co-founded the Centre for Educational Policy Studies (CEPS, 2001) at the University of Ljubljana and has been its director until today. He was the founder and the first President of the Slovenian Educational Research Association (SLODRE) and took part as a member (2011-2017) in the Council of the European Educational Research Association (EERA). He is a member of the Consortium for Higher Education Research (CHER). 
Open Access This chapter is licensed under the terms of the Creative Commons Attribution 4.0 International License (http://creativecommons.org/licenses/by/4.0/), which permits use, sharing, adaptation, distribution and reproduction in any medium or format, as long as you give appropriate credit to the original author(s) and the source, provide a link to the Creative Commons license and indicate if changes were made.

The images or other third party material in this chapter are included in the chapter's Creative Commons license, unless indicated otherwise in a credit line to the material. If material is not included in the chapter's Creative Commons license and your intended use is not permitted by statutory regulation or exceeds the permitted use, you will need to obtain permission directly from the copyright holder. 